NikLaI Patrícia Dominika

DOI: 10.15170/DIKE.2021.05.01.11

PhD-hallgató

PTE ÁJK

\title{
A szórvány magyar tanköteles gyermekek családon kívüli elhelyezése Baranyában az 1941-1942-es tanévben
}

\section{The Placing of Hungarian Compulsory School Children outside the Family in County Baranya in the 1941-1942 School Year}

The framework for the placing of Hungarian compulsory school children outside the family was based on the 25.360/1941. Religion and Public Education Ministerial decree, which constituted new provisions from the 1941/1942 school year for the education of native Hungarian children living in non-Hungarian environment. The reason for issuing the decree was the growing demand of the nationalities for education in their native language, which the Hungarian state - after the failure of the unified education system introduced in 1935 - made available to them in 1941. This measure was supported by nationalities as well, but at the same time we must not forget that the Horthy-era represented a strong national policy, and the patriotic, national education began in elementary school. Thus, the education of Hungarian children could not be neglected while striving to fulfil the needs of nationalities. According to paragraph 1 of the 25.360/1941. Religion and Public Education Ministerial decree on the education of Hungarian children: 'A native Hungarian compulsory school child living in Hungary, who stays in a not native Hungarian environment must be educated in a Hungarian school or class, by a traveling teacher, in a Hungarian boarding school, or in another native Hungarian environment.' The placing of children outside the family was only necessary if there was no school with Hungarian educational language in the municipality, because in that case 'a native Hungarian child living in the municipality (city) can only be sent by his or her tutelary to such a school, until reaching the age of compulsory schooling.' In accordance with the decree, from the summer of 1941 the Education Inspectorate collected data on the native Hungarian compulsory school children who lived in a non-Hungarian environment to provide them enrolment elsewhere. The first version of the options listed in the decree (Hungarian school or class in municipality) is not the subject of the study, since in that case, the child remains in the family. The second version - a traveling teacher - would not cause change either, but I did not find any example of this in the archives anyway. What may be more interesting in the terms of Family law is the placing in a boarding school or with a family of a relative or acquaintance in native Hungarian environment - this is indicated by the phrase in an otherwise 'native Hungarian environment'. I give examples of these cases - boarding school and placement in Hungarian families - from practice based on archival records.

Keywords: native language education, boarding school, placing outside the family, education of Hungarian compulsory school children as minority 


\section{A szórvány magyar tanköteles gyermekek iskoláztatásának jogszabályi háttere}

A szerző doktori kutatása elsősorban a közoktatásügy jogtörténeti fejlődéséhez kapcsolódik, ám ezen belül a tanköteles gyermekek vonatkozásában időről időre előkerülnek a levéltárban olyan érdekes források, amelyeket érdemes más szemszögből - jelen esetben családjog-történeti oldalról - is megvizsgálni. A tanulmány levéltári eseteket dolgoz fel, célja ennek megfelelően rövid betekintést nyújtani az 1941-1942-es tanév munkálatainak gyakorlatára a nem magyar környezetben élő gyermekek családon kívüli elhelyezése tekintetében. A témaválasztás indoka mellett magyarázatot igényel a címben szereplő „szórvány magyar tanköteleseknek” a köre. A szórvány jelzôt használták a korabeli iratokban, amely arra utalt, hogy az érintett magyar gyermekek olyan községben laktak, ahol a lakosság többsége nem magyar volt, hanem például német, horvát, szerb, mivel Baranyában elsősorban ezek a nemzetiségek voltak számottevőek, sok községben ők voltak többségben a magyarokhoz képest.

A szórvány magyar tanköteles gyermekek családon kívüli elhelyezésének keretét a 25.360/1941. sz. Vallás és Közoktatásügyi Miniszteri rendelet adta, amely az 1941-1942-es tanévtől kezdődően írta elő a nem magyar környezetben élő magyar anyanyelvú gyermekek oktatására vonatkozó új rendelkezéseket. A rendelet kiadásának indoka a nemzetiségek anyanyelvi oktatás iránti egyre növekvő igénye volt, amelyet a magyar állam végül az 1935-ben bevezetett egységes oktatási rendszer sikertelenségét követően 1941-ben tett lehetővé számukra. Ez az intézkedés a nemzetiségek részéről támogatásra is talált, ugyanakkor nem szabad megfeledkeznünk arról, hogy a Horthy-korszak erőteljes nemzeti politikát képviselt, amelyben a hazafias, nemzeti nevelés már az iskolában elkezdődött. ${ }^{1}$ Az iskolai kötelezettségről és a nyolcosztályos népiskoláról szóló 1940. évi XX. tc. 1. S (1) bekezdésben is ez tükröződött vissza: „A népiskola feladata, hogy a gyermeket vallásos és erkölcsös állampolgárrá nevelje, illetóleg a nemzeti müvelódés szellemének megfeleló általános és gyakorlati irányú alapmüveltséghez juttassa és ezáltal az életben való helytállásra és további tanulmányokra is képessé tegye. Ezért minden gyermek gondviselöjének (atyjának, gyámjának, gazdájának) gondoskodnia kell arról, hogy a gondviselése alatt álló gyermek népiskolai oktatásban és nevelésben részesüljön."2

Ennek megfelelően kialakult a rendszer kettőssége, hiszen nem lehetett elhanyagolni a magyar gyermekeket sem amellett, hogy törekedtek a nemzetiségek igényeinek kielégítésére. ${ }^{3}$ Utóbbiakról, azaz a nem magyar anyanyelvú gyermekek népiskolai oktatásáról a 25.370. sz. Vallás és Közoktatásügyi Miniszteri rendelet szólt, a tanulmány témája szempontjából viszont az ezt közvetlenül megelőző 25.360/1941. sz. Vallás és Közoktatásügyi Miniszteri rendelet releváns, amely a magyar anyanyelvű gyermekek iskoláztatásáról rendelkezett. Ez utóbbi rendelet 1. \-a értelmében a „Magyarorşág területén lakó olyan magyar anyanyelvü iskolaköteles gyermeket, aki nem magyar anyanyelvü környezetben él, magyar iskolai tagozatban, vándortanitó útján, magyar internátusban, vagy egyébként

\footnotetext{
${ }^{1}$ A szerző további tanulmányai az egységes illetve a teljes anyanyelvi oktatási rendszer bevezetésének gyakorlatáról illetve a Horthy-korszak nemzeti neveléséről és oktatáspolitikájáról: NiKLAI, A kisebbségi iskolaügy Balázs Ferenc tevékenysége alapján 81-107.; NiKLAI, Magyar kultúrpolitika. Közoktatásügyi igazgatás Baranyában 86-99.; NIKLAI, Die Volksunterrichtspolitik von Bálint Hóman und die Schulgründungen im Komitat Baranya 249-259.

2 1940. évi XX. törvénycikk az iskolai kötelezettségről és a nyolcosztályos népiskoláról.

${ }^{3}$ A nemzetiségek oktatásának gyakorlatáról lásd például: FÜZES, A nemzetiségi oktatás szervezési problémái a baranyai népiskolákban; SzITA, A magyarországi németség iskolaügyének alakulása a Délkelet-Dunántúlon.
} 
magyar anyanyelvü környezetben elhelyezve kell iskoláztatni." A már idézett 1940. évi XX. tc. 1. \(2) bekezdése alapján ugyan „A gondviselönek jogában van a gyermeket akár lakóbelyén, akár más községben lévő és bármilyen jellegü nyilvános népiskolába beiratni és járatni." 5 , hozzátehetjük, hogy a gyermekek családon kívüli elhelyezése értelemszerűen csak akkor volt szükséges, ha nem múködött a községben magyar tanítási nyelvű iskola, mert abban az esetben a 25.360/1941. sz. Vallás és Közoktatásügyi Miniszteri rendelet 2. S szerint „a községben (városban) lakó magyar anyanyelvü gyermeket iskolaköteles korának betöltééeig gondviselóje csak ilyen iskolába járathatja.

\section{A szórvány magyar tanköteles gyermekek elhelyezésének gyakorlata}

A 25.360/1941. sz. Vallás és Közoktatásügyi Miniszteri rendeletnek megfelelően Baranya vármegye és Pécs város tanfelügyelősége 1941 nyarától kezdődően adatokat gyüjtött a magyar anyanyelvú, nem magyar környezetben élő, azaz szórvány magyar tankötelesekről, hogy számukra a máshol történő beiskolázást biztosítsák. Erre irányuló szervező munkálatok sokaságával találkozhatunk a Magyar Nemzeti Levéltár Baranya Megyei Levéltárában Baranya vármegye és Pécs város tanfelügyelőségének iratai között az 1941 -es évre vonatkozóan.

A rendelet 1. \-ában felsorolt lehetőségek között az első a magyar iskolai tagozat, amely nem tárgya a vizsgálatnak, hiszen ekkor a családban marad a gyermek. A második eset vándortanító - szintén nem járna változással. Családjogi vonatkozásban érdekesebbek lehetnek a további megoldások, így az internátusi, továbbá a rokonnál, ismerősnél való elhelyezés - utóbbira utal az „egyébként magyar anyanyelvü környezetben elhelyezve” fordulat. A tanulmányban ezekre az esetekre láthatunk példákat a gyakorlatból a levéltári iratok alapján.

\section{1. Családi elhelyezés}

Az iskolai hatóságok - általában az iskolaszékek - összeírásokat készítettek a magyar anyanyelvű tankötelesekről, akik olyan községben laktak, ahol nem működött magyar tagozat. ${ }^{7}$ Az összeírás a vizsgált tanévben az 1927. szeptember és 1935. június 30. között született gyermekeket érintette, ez a korosztály volt ekkor tanköteles korban, az ô részükre volt szükséges az oktatás családon kívüli elhelyezéssel történő megvalósítása. Az elhelyezés történhetett családnál, ismerős személyeknél vagy internátusban, amelyről a következő fejezetben lesz szó.

\footnotetext{
${ }^{4}$ A m. kir. vallás- és közoktatásügyi miniszter 1941. évi 25.360. számú rendelete a magyar anyanyelvű gyermekek iskoláztatásáról.

5 1940. évi XX. törvénycikk az iskolai kötelezettségről és a nyolcosztályos népiskoláról.

${ }^{6}$ A m. kir. vallás- és közoktatásügyi miniszter 1941. évi 25.360. számú rendelete, a magyar anyanyelvű gyermekek iskoláztatásáról.

7 Lásd például: MNL BAML XIV. 70. 1527-2/1941, 2245/1941, 1527-5/1941, 1527-7/1941, 1527-8/1941, $1527-$ 4/1941, 1527-11-12-9/1941, 1527-13/1941, 1527-14/1941, 1527-18/1941, 1527-19/1941, 1527-21/1941, $1527-$ 23/1941, 1527-24/1941, 1527-27/1941, 1527-30/1941, 1527-33/1941, 1527-34/1941, 1527-36/1941, 1527-37/1941, 1527-38/1941, 1527-39/1941, 1527-41/1941, 1527-49/1941, 1527-52/1941, 1527-56/1941, 1527-57/1941, 152758/1941, 1527-59/1941, 1527-60/1941, 1527-61/1941, 1527-65/1941, 1527-68/1941, 1527-78/1941, 1527-79/1941, 1527-80/1941, 1527-81/1941, 1527-82/1941, 1527-106/1941.
} 
A családi elhelyezés menetében az iskolai hatóság 1941 nyarán felhívta a szülők figyelmét a jogszabályi változásra, miszerint gyermekük oktatásáról magyar anyanyelvű környezetben kötelesek gondoskodni. Amennyiben ez lakóhelyükön nem valósulhatott meg, mert nem volt magyar nyelvü tagozat a helyi iskolában, a szülők kötelessége volt megfelelő személyt találni, akire gyermeküket rábízzák. Az ellátásadó személyének meghatározását követően számtalan nyilatkozat benyújtása volt szükséges mind az ő, mind a szülők részéről az iskolaszéken keresztül a tanfelügyelőségnek, amely azután felterjesztette az iratokat a Vallás és Közoktatásügyi Minisztériumba.

A szülő illetve gondviselő nyilatkozatot tett, amelyben kifejezte, hogy iskolaköteles gyermekét magyar nyelvű iskoláztatás és nevelés biztosítása céljából magyar környezetű, magyar családnál kívánja elhelyezni, majd megjelölte az ellátásadó személyt. Legtöbbször szükséges volt megadni a foglalkozását, családi illetve lakhatási körülményeit is. Ezzel együtt a gondviselő kérhette az ellátásadó részére a vallás és közoktatásügyi miniszter által kilátásba helyezett 35 pengő havi megtérítési díjat. ${ }^{8}$ Ha több gyermek lett elhelyezve valakinél, akkor azok után fejenként 35 pengő járt. Fontos támogatás volt az állam részéről, hogy azok, akiknél a gyermeket elhelyezték, kaptak az ellátás biztosításának támogatására 35 pengőt. Az ellátási díj havi összege 1942. március hónaptól a vallás- és közoktatásügyi miniszter rendelkezése folytán 40 pengőre emelkedett ${ }^{9}$, majd 1944. január 1-től 70 P/hó volt az összege. ${ }^{10}$ Ezt a szülők lehetőségeikhez mérten olykor kiegészítették néhány pengővel - átlagosan 15-20 pengő körüli összeggel, de ritkán akár 80 pengővel is, bár ez utóbbi esetében kifejezetten hozzá is tették az iratokhoz, hogy az elhelyezendő gyermek apja vagyonos ember -, illetve természetbeni szolgáltatással (amelynek mértékét szintén pengóben határozták meg), ezekről említést tettek a nyilatkozatokban vagy későbbi levelezésekben; előfordult olyan is, ahol azt emelték ki, hogy mivel közeli rokonokhoz lett elhelyezve a gyermek, nem meghatározott összeggel egészítik ki az állami támogatást, hanem szükség szerint kölcsönösen támogatják egymást. ${ }^{11}$

Ezzel együtt az ellátásadó nyilatkozott arról, hogy a rábízott tanköteles részére teljes ellátást ad, megfelelő egészséges lakást, világítást, fütést, mosást, elégséges étkezést biztosít, a gondviselésére bízott gyermekek testi és lelki nevelődését előmozdítja, valamint egy másik dokumentumban nyilatkozott annak érdekében, hogy a számára járó díjat megkapja. ${ }^{12}$ Mindehhez szükség volt még az iskolaigazgató vagy a tanító által kiállított igazolványra arról, hogy a gyermek az iskolába beiratkozott, illetve mikor iratkozott be ${ }^{13}$; a beiratkozás időpontjának az ellátásadó szempontjából volt jelentôsége, ettôl is függhetett például a részére kiutalható díj folyósításának kezdő napja. Néhány esetben megtörtént az is - a beiratkozás napjának megjelölése mellett - hogy

\footnotetext{
${ }^{8}$ MNL BAML XIV. 70. 1527-12-13/1941, 1527-14/1941, 1527-III-17/1941, 1527-III-18/1941, 1527-34/1941, 1527 39/1941, 1527-III-25/1941, 1527-III-21/1941, 1527-14-26/1941, 1527-27-24/1941, 1527-32/1941, 1527-33/1941, 1527-27-87/1941, 1527-22/1941, 1527-23/1941, 1527-III-41/1941, 1527-III-42-1941, 1527-III-43/1941, 1527-III44/1941, 1527-III-45/1941, 1527-III-46/1941, 1527-III-47/1941.

${ }^{9}$ MNL BAML XIV. 70. 44-III-21-29-39/1942, 110-1/1942.

${ }^{10}$ MNL BAML XIV. 70. 80.125/1944.

${ }^{11}$ Lásd például: MNL BAML XIV. 70. 464/1942, 1527-III-38/1941, 438/1943, 3979/1943.

12 MNL BAML XIV. 70. 1527-12-13/1941, 1527-14/1941, 1527-III-17/1941, 1527-III-18/1941, 1527-34/1941, 1527 -

39/1941, 1527-III-25/1941, 1527-III-21/1941.

${ }^{13}$ MNL BAML XIV. 70. 1527-12-13/1941, 1527-14/1941, 1527-III-17/1941, 1527-III-18/1941, 1527-34/1941, 1527 -

39/1941, 1527-III-25/1941, 1527-III-21/1941.
} 
a gyermek beiratkozott a magyar tagozatba, magyar környezetben kapott oktatást, ugyanakkor a kijelölt ellátásadó elutasítja az ellátási dij felvételét, jelezve, hogy végül nem lett elhelyezve nála a gyermek, mert például át tud járni valamilyen módon naponta az iskolába. ${ }^{14}$

A nyilatkozatok körében szükséges volt még az, hogy az ellátásadó személyéről nyilatkozzon a helyi iskolai hatóság részéről valaki, például a helyi plébános, körzeti iskolafelügyelő, távolabb eső elhelyezés esetén jellemzően az ottani tanfelügyelő; ennek a nyilatkozatnak a szövege a következő volt: „S ¿ives felkérésre értesitem, hogy ... nevü magyar anyanyelvü tanköteles ... nevú ellátásadója erkëlcsi-, nemzeti- és magyarsági magatartás tekintetében kifogástalan személy/kifogásolható, mert... Az. ellátásadó lakása nevezett iskolaköteles testi fejlödése szempontjából megfelelö/nem megfeleló, mert... Ugyszintén nevezett gyermek rendes világitást, fütést, mosást és elégséges étkezést kap/nem kap, mert... Tiszৃtelettel véleményezem, hogy nevezett tanulók testi és lelki nevelödése mostani ellátásadójánál bižtositva van / nincs biztositva, mert... Eq̨en kivül kö̋löm, hogy...”. Az ellátásadót ezek alapján vizsgálták elsősorban a korszak oktatáspolitikájának megfelelő nemzeti vonatkozásban, ezen felül ki kellett térni lakhatási körülményeire, a gyerekek testi-lelki fejlődésével kapcsolatos szempontokra, valamint a formanyomtatvány végén lehetett egyéb megjegyzéseket tenni ${ }^{15}$, itt általában az ellátásadót méltatták valamilyen formában, egy esetben ezt füzik hozzá például: „Ežnkiviül jelentem, hogy a tankötelest meglátogattam, aki megfázás folytán ágyban feküdt. Ellátásadója kellemesen fütött, meleg szobában, tiszta ágynemübe fektetve, gondosan ápolta. A tanköteles igen jól érzi magát ebben a tisztességes körmyezetben" "16, máskor pedig azt, hogy az ellátásadó „a tanulóknak nagyapja, igy a szülei báz. után a legjobb és legbiztonságosabb belyen vannak." "17

Olykor előfordult, hogy hiába állították ki a nyilatkozatot a fenti tartalommal, később kiderült, hogy adott ellátásadó személy mégsem felel meg bizonyos kritériumoknak. Egy harci ellátásadóról a gyermek elhelyezésekor a plébános úgy nyilatkozott, hogy erkölcsi, nemzeti, magyarsági és egyéb szempontból kifogástalan, „minden tekintetben feddhetetlen életü ember és igy állami alkalmazásban is van”. ${ }^{18} \mathrm{Az}$ elhelyezésről szóló nyilatkozatban a gondviselők leírták az ellátásadó körülményeit is: „útör, gyermeke 15 éves leány, lakás 2 sqoba konyha, egészséges”, amelyek szintén arra utalnak, hogy a gyermek ellátását megfelelően képes biztosítani. A körjegyző írt a tanfelügyelőnek, hogy „a kislány apja Erdélyben van munkán sigy nem hallgatható meg, de a német anyanyelvü anya nyilatkozott ugy, hogy magyar nyelven való oktatást kivánják.”. ${ }^{19}$ Ezt követően azonban 1942. február 12-én a tolnai tanfelügyelő arról számolt be Magyar Dęső baranyai tanfelügyelőnek, hogy „Pintér Eræ̌sébet Harcon lévö magyar szórvány iskolakötelest régi szállásadójától és gondozójától Szakál Józseftól elvettéke, illetve atyja elhelyeżte, mert valláserkölcsi nevelést nem latták teljesen biztositottnak a család tagjainak magatartása és beszéde miatt. Jelenleg az ottani kántortanitónál, Páli Györgynéál kapott elhelyezést a szokásos állami 35 P és a szülóktöl bižtositott 15 P havi ellátási díj fejében."20

\footnotetext{
${ }^{14}$ Lásd például MNL BAML XIV. 70. 1527-III-18/1941.

${ }^{15}$ MNL BAML XIV. 70. 1527-242/1941, 1527-14/1941, 1527-12-13/1941, 1527-III-17/1941, 1527-III-18/1941, 1527 -

34/1941, 1527-39/1941, 1527-III-21/1941.

16 MNL BAML XIV. 70. 1527-III-17/1941.

${ }^{17}$ MNL BAML XIV. 70. 1527-32-33/1941.

${ }^{18}$ MNL BAML XIV. 70. 1527-III-25/1941, 464/1942.

19 MNL BAML XIV. 70. 1527-104/1941.

${ }^{20}$ MNL BAML XIV. 70. 1527-III-25/1941, 464/1942.
} 
A családi elhelyezéssel kapcsolatban egy problémás esetet jelentett, ha az elhelyezés megtörtént, azonban tanév közben változás állt be a körülményekben. Előfordulhatott, hogy az elhelyezés helyén szűnt meg a magyar tanítás, vagy épp ellenkezőleg, a gondviselő lakhelyén indult magyar tagozat, így az elhelyezés szükségtelenné vált, haza lehetett hívni a gyermeket. Ez utóbbira példa az erdősmecskei kislány esete, akit szülei Somogy vármegyébe küldtek el egy rokonhoz, időközben azonban új tanítónő érkezett Erdősmecskére és megkezdődött a magyar nyelvű tanítás; értesítették a szülőket, hogy gondoskodjanak gyermekük hazaszállításáról, mivel családon kívüli elhelyezése ezzel tárgytalanná vált. A baranyai tanfelügyelő felkérte ennek megfelelően a somogyi tanfelügyelőt, hogy a kislány ellátásadójának az addig járó dijat fizesse ki és tájékoztassa az ellátás megszűnésének időpontjáról. A kislányt végül nem tudták rögtön hazavinni, mert - ekkor éppen január volt - az apja elmondta, hogy az iskola Erdősmecskén 3 és fél km-re van a lakásuktól, így hóban, hidegben nem küldheti a gyereket ilyen távolságról az iskolába. Ezt követően a tanfelügyelő rögtön intézkedett is, értesítette a somogyi tanfelügyelőt, hogy a kislány mégis maradhasson annál a rokonnál, akinél eredetileg elhelyezték a tanévre. ${ }^{21}$ Hasonló ehhez az esethez a Szeged-Röszkén a helyi plébánosnál elhelyezett ${ }^{22}$ kislány története, viszont a tanévet már nem töltötte el ott, mivel a plébános - kérve a támogatás folyósításának beszüntetését - arról számolt be a szegedi, illetve ezután a pécsi tanfelügyeségnek, hogy a kislány szülei Kárászra (Baranya) költöztek, ahol magyar nyelvú iskolába járhat, így a karácsonyi szünet után már nem küldték vissza kislányt, hanem rövid ideig magántanító oktatta, márciustól pedig a kárászi iskolába iratkozott be. ${ }^{23}$

Több elhelyezés mutatja azt is, hogy a szülők a legkülönbözőbb helyekre küldték gyermekeiket aszerint, kinek hol volt épp ismerőse, rokona, ahol magyar környezetben, magyar családnál elhelyezve tanulhatott a gyermek, így például Baranyából Dunaföldvárra (Tolna), Alsósegesdre (Somogy), Tótkomlósra (Békés), Szegedre (Csongrád) is utaztak a gyermekek az ellátásadójukhoz. ${ }^{24} \mathrm{Az}$ ismerősök és rokonok mellett gyakori volt az is, hogy a tanításban közremúködő személyeknél, így például tanítónál, kántornál, plébánosnál helyezték el a gyermekeket. Sajnálatosan előfordult, hogy adott községben lett volna magyar tagozat, a tanítói állás betöltetlensége miatt azonban a szülők arra kényszerültek, hogy ők is gondoskodjanak gyermekük családon kívüli elhelyezéséről, noha alapvetően a községben kellett volna magyar oktatásnak múködnie. ${ }^{25}$

A családi elhelyezés és az internátus közötti átmenetként, ám még inkább előbbihez tartozóként értékelhetô a következő eset: A szederkényi körjegyző leányát a németbólyi magyar tagozatba íratta be, ott zárdánál helyezte el, ehhez kérte a 35 pengő segélyt. Kérését azzal indokolta, hogy a zárda nem minôsül internátusnak (ahova szintén beadhatná gyermekét), mivel ott más gyermekek nem laknak, csak apácák, akik szívességből fogadták be az ő lányát. A zárda apácái magyar tanítónők és óvónők, ezzel is alátámasztotta kérelmét, miszerint magyar nyelvű környezetben helyezi el lányát. Internátusba nem szeretné gyermekét adni, mert „önállóan ölttözködni és fésülködni még nem tud.” Erre tekintettel szerette volna igénybe venni a 35 pengő segélyt, amelyet a

\footnotetext{
${ }^{21}$ MNL BAML XIV. 70. 1527-III-39/1941.

22 MNL BAML XIV. 70. 1527-104/1941.

${ }^{23}$ MNL BAML XIV. 70. 115/1942, 44-III-20/1942.

${ }^{24}$ MNL BAML XIV. 70. 1527-III-17/1941, 1527-39/1941, 1527-III-25/1941, 1527-III-21/1941.

${ }^{25}$ Lásd például: MNL BAML XIV. 70. 1527-III-40/1941.
} 
zárdának kért kiutalni lánya után. A tanfelügyelőség először elutasította a körjegyző kérelmét, arra hivatkozva, hogy az ellátási díj csupán családi elhelyezés esetén jár, azonban a körjegyzô második kérésére már arról tájékoztatta, hogy a Vallás- és Közoktatásügyi Minisztérium méltányolta a kérést, így kiutalható a díj a zárdának is, ezt követően a körjegyző külön köszönetet nyilvánított a ,jóindulatu pártfogásukért” és ismét beküldte a zárda és maga részéről a szükséges nyilatkozatokat. Érdekességként megemlítendő, hogy ebben az esetben is található az állami 35 pengő támogatáson felüli hozzájárulás a szülők részéről, itt ez a zárda nyilatkozatából derül ki, amelyet a szokásos mintán felül a következőképpen egészítettek ki: „(...) magyar anyanyelvú tanköteles részére teljes ellátást adok - 60 P, azaz hatvan pengöért - megfelelö egészséges lakást, világitást, fütést (...)” 26

\section{2. Internátusi elhelyezés}

A családi elhelyezés mellett gyakori volt még az internátusi elhelyezés, ennek menetére láthatunk eseteket az alábbiakban. Baranyában internátusi elhelyezés Pécsett és Mohácson volt lehetséges. Amennyiben a gondviselő ilyen módon kívánt gondoskodni gyermeke magyar környezetben történő iskoláztatásáról, egy rövid nyilatkozatot kellett benyújtania annak megjelölésével, hogy Pécsett vagy Mohácson helyezné el gyermekét. ${ }^{27}$

Az ivándárdai magyar anyanyelvű tankötelesek gondviselői úgy nyilatkoztak, hogy gyermekeiket nem tudják magyar jellegű községben családoknál elhelyezni. A községben alacsony a magyar tankötelesek száma, az 1941-1942. tanévben csupán 3 (összesen 12 a németekkel együtt), ezért az iskolaszék azzal a kéréssel fordult a tanfelügyelőséghez, hogy esetleg helyben oktathassák a magyarokat is. Hozzátették, ha ez nem megoldható, akkor internátusban való elhelyezéssel kívánják gyermekük oktatását biztosítani. A köztes megoldás nem lett elfogadva, a tanfelügyelő arra kérte a plébánost, nyilatkoztassa a szülőket, hogy mohácsi vagy pécsi internátusba küldenék gyermekeiket. A szülők Mohácsot választották. Az egyik testvérpár apja azzal fordult a tanfelügyelőhöz, hogy cseléd ember, felesége beteg, így nem tudja rendesen ruhával és cipővel ellátni gyermekeit annak érdekében, hogy internátusba adhassa őket. Kérte a tanfelügyelőt, hogy biztosítsa róla, gyermekeit „tetôtól talpig felrubázzák és teljes ellátásban biztositják”” és ebben az esetben „készséggel teljesitem hazám iránti kötelességemet” A tanfelügyelő erre válaszul tájékoztatta, hogy a kérést, miszerint a tanfelügyelői hivatal ruháztassa fel gyermekeit, nem tárgyalhatja, hanem ebben az ügyben forduljon a község elöljáróságához. Hozzátette azonban, hogy az internátusban való elhelyezés teljesen díjtalan, azt a Vallás- és Közoktatásügyi Minisztérium biztosítja, azzal, hogy a szülőknek gondoskodniuk kell gyermekeik ruházatáról. ${ }^{28} \mathrm{~A}$ díjtalan internátusi elhelyezés mellett is komoly gondot okozott többeknek a ruháztatás, erről számolt be még például a káni szülők levele is. $^{29}$

Az internátusba való felvételt utólagosan kérte két gyermek szülői nevében az iskolaszéki elnök. Az egyik esetben német vezetéknevű családról volt szó, akik a nevük miatt tévedésből nem

\footnotetext{
${ }^{26}$ MNL BAML XIV. 70. 1527-105/1941.

${ }_{27}$ MNL BAML XIV. 70. 1527-4/1941, 1527-7/1941, 1527-33/1941, 1527-59/1941, 1527-86/1941, 1527-87/1941, 1527-96/1941, 1527-97/1941, 1527-98/1941, 1527-104/1941.

28 MNL BAML XIV. 70. 1527-5/1941.

${ }^{29}$ MNL BAML XIV. 70. 1527-36/1941.
} 
lettek korábban megkeresve a magyar tagozat ügyében, mert a tanító, aki tudhatott volna a magyar anyanyelvről, éppen egy német tanítói tanfolyamon tartózkodott a magyar anyanyelvúek összeírása idején. A kisjakabfalvai iskolaszéki elnök előadta, hogy a fiú jobban beszéli a magyar nyelvet, mint a németet amellett, hogy egyébként is magyar anyanyelvűnek vallják magukat. A villányi plébános mint iskolaszéki elnök kérte egy másik kisjakabfalvi gyermek felvételét a mohácsi vagy a pécsi internátusba. A szintén német hangzású nevű apa a plébános elmondása szerint teljesen magyar érzésű ember, aki fiából is magyar embert akar nevelni és szeretné, ha továbbtanulhatna, ezért is szükséges lenne számára a nyelvgyakorlás magyar környezetben. Hozzátette, hogy a magyar anyanyelvűség bizonysága például az is, hogy a fiú korábban a vallástant is magyarul tanulta. Az utóbbi család szintén lemaradt a jelentkezésről a magyar anyanyelvűek összeíráskor. ${ }^{30} \mathrm{~A}$ villányi plébános egy villánykövesdi kislány esetében is arról számolt be, hogy a németes hangzású családnév és a tanító távolléte miatt lemaradt a jelentkezésről, de ôt is a magyar anyanyelvűek közé kellett volna sorolni; a lány apja ennek megfelelően kérte a pécsi internátusba való felvételét, illetve - amennyiben az nem lehetséges - igény tartana a 35 pengő díjra, hogy Pécsett rokonnál helyezze el. Az édesapa indoka a következő volt: „magam magyar anyanyelvü iparos vagyok, szeretném, ha kislányom magyar iskolába járna és magyar anya válna belöle." 31 Mindezen esetek hűen tükrözik a korszellemet a nemzeti nevelés vonatkozásában.

Az internátusi elhelyezésre - a magyar nyelvű nevelés melletti hazafias érdeken felül - igen változatos indokok állnak rendelkezésünkre, így például a lapáncsai plébános a magyar tanköteles gyermekek magyar nyelvű beiskolázására vonatkozó jelentésében egy tanulóval kapcsolatban arra hivatkozva támogatta az internátusi elhelyezést, hogy a gyermek , zilált családi körülmények között van”; ez alatt azt értette a plébános, hogy a leány anyja elvált és vadházasságban él egy új férfival, nekik a gyermek otthon „útban van s nincs is hová tenni”. Később a plébános arról tájékoztatta a tanfelügyelőt, hogy elköltöztek a községből olyan helyre, ahol van magyar iskola. ${ }^{32}$

Az internátusok szervezési és építési munkálatai elhúzódtak, a kérvényeket az ottani elhelyezésre leadták a tanév kezdetén, azonban a gyermekek behívása nem történt meg ekkorra. Erre tekintettel Magyar tanfelügyelő felkérte az érintett iskolai hatóságokat, hogy azok tájékoztassák a szülőket, gondviselőket a helyzetről, az internátusokba beutalt gyermekek gondviselői gyermeküket ideiglenesen abba az iskolába járassák, ahova eddig, amíg az internátusok megkezdik működésüket. Hozzátette azt is, hogy „sziveskedjék intézkedni, hogy a nem magyar oktatási nyelvü iskola tanitója - amennyiben erre idó és mód van - a pár hónapban külön is foglalkoztassa a magyar anyanyelvú gyermekekeet. ${ }^{\prime 33}$ A megvalósulásra láthatunk támogató és ellentétes példákat is. A baranyaszentgyörgyi plébános válaszából következtethetünk arra, hogy a tanfelügyeló által megfogalmazott átmeneti oktatás megvalósult. A helyi szülők gyermekeiket mind a pécsi internátusban szerették volna elhelyezni. ${ }^{34}$ A plébános tájékoztatta a tanfelügyelőt, hogy a baranyaszentgyörgyi római katolikus, nem magyar tanítási nyelvú iskolába a tanév kezdetétől járnak rendszeresen a magyar gyermekek is, ahol külön magyar oktatásban részesülnek. Egyben azzal a kéréssel fordult a tanfelügyelőhöz, hogy

\footnotetext{
${ }^{30}$ MNL BAML XIV. 70. 1527-7/1941, 1527-21/1941.

${ }^{31}$ MNL BAML XIV. 70. 1527-21/1941, 547/1941, 568/1941.

32 MNL BAML XIV. 70. 419/1941.

33 MNL BAML XIV. 70. 1527/1941.

${ }^{34}$ MNL BAML XIV. 70. 1527-26/1941.
} 
a tanító részéről ideiglenesen tekintsen el a heti óraterv készítésétől a sok munkájára tekintettel, „mert a magyar nyelvü gyermekek. külön oktatását e nélkül is lelkiirsmeretesen végzi. Nevezett tanitó eddigi munkája és érzelmi beálitottsága ezt valóban igazolja. ${ }^{’ 35}$ Ezzel szemben Somberekről egy édesanya arról panaszkodott, hogy gyermekét szeretné magyar nyelvű környezetben taníttatni, de egyelöre kénytelen a helyi német iskolába járatni - mert a mohácsi internátusból „sajnos semmi sem lett”-, ahol „magyarul egyáltalán nem foglalkoznak. vele, úgy a gyermeknek csak szenvedés reggel 1/2 9-töl d.u. 4-ig ott ülni és egy szót sem ért az egész. tanitásból.” Kifejezte aggodalmát azért is, hogy messzirôl kell bejárnia a gyermeknek rossz időben is a német tanításért, amelynek így az édesanya nem látja értelmét, majd hozzátette azt is, hogy „inkább veszitsen egy évet, mint hogy német szellemben neveljék.” ${ }^{36}$ Utóbbi kifogásban érezhetünk túlzott nacionalizmust is, ami a korszakban igen divatos volt, ugyanakkor a németbarát irányultságú politika ismeretében mégis érdekes, hogy a levéltári dokumentumok azt mutatják, hogy általában e két irány - a hangsúlyozott nemzeti érzés és a németbarát irányultság - együtt jelentkezett.

\section{3. A szülők indítványai harmadik megoldásra}

A szülők, gondviselők több alkalommal hangoztatták elégedetlenségüket a lehetőségeikkel kapcsolatban, így - amellett, hogy kivétel nélkül kifejezték a magyar nevelés iránti elkötelezettségüket, a rendelkezésekkel való hazafias egyetértésüket - panaszt fogalmaztak meg a családon kívüli elhelyezés minden formájával szemben. Többekben felmerült, hogy az ellátás diján magántanítót vagy rendes tanítót alkalmazhatnának a helyi iskolában, ha több gyermek családjának járó elhelyezés díját összesítve erre fordíthatnák. A probléma itt azzal volt, hogy a rendelet a magyar nyelvű környezetben való elhelyezést helyezte előtérbe, nem volt elegendő a magyar nyelvú oktatás önmagában, ennek megfelelően az ilyen kéréseket rendre elvetették.

A mágocsi iskolaszéki elnök beszámolt a tanfelügyelőnek a helyi magyar szülők méltatlankodásáról. Felhívta a szülőket, nyilatkozzanak, hogyan kívánják gyermekeik magyar nyelvű tanítását biztosítani, mire egyhangúan azt felelték, hogy sem internátusban, sem magyar jellegú más községben nem akarják elhelyezni őket családon kívül, hanem kérik, hogy bármi egyéb módon tegyék lehetôvé, hogy gyermekeik Mágocs-kispusztán tanulhassanak. 11 tanköteles gyermekről volt szó, így felhozták indokkét a magas állami költségeket máshol való elhelyezésük esetén, amelyből - indokolásuk szerint - akár egy magyar tanítót is kaphatna a község. Felháborodásukat az is táplálta, hogy a községben a német tagozat úgy került felállításra, hogy a 11 magyar gyermekkel szemben csupán 15 német anyanyelvű gyermek volt, így a szülők álláspontja szerint „ôk is kérhetik ugyanazon jogokat saját gyermekeik érdekében”. A főjegyző végül hozzátette, hogy a rendelkezés nagy elkeseredést szült a magyar szülők körében. ${ }^{37}$

Sombereken a plébános szintén leírta, hogy „a szülök általában vonakodnak gyermekeiket internátusba adni, és sokkeal inkább ąt kivánják, hogy a tanitó külön órárás révén tanitsa helyben a gyermekeiket.” Az egyik édesanya kijelentette, hogy „internátusba nem adhatja gyermekeit, de privát helyre

\footnotetext{
35 MNL BAML XIV. 70. 351/1941.

36 MNL BAML XIV. 70. 1527-69/1941.

${ }^{37}$ MNL BAML XIV. 70. 1527-41/1941.
} 
sem, egyáltalában nem akarja, hogy Sombereket elhagyják, azaz a szülöi házat. Ažt kéri és akarja, hogy járjanak a német nyelvü iskolába, németül öke értenek, de ö valamelyik. tanitó vagy tanitónö révén akarja öket otthon magyar nyelven oktatni és gyermekeinek magyar nyelvü tanittatását igy biztositani. Más tartalmú nyilatkozatot nem bajlandó aláirni." A három gyermek édesapja ekkor katonai szolgálatot teljesített, emiatt az anya volt jogosult nyilatkozni. ${ }^{38}$

A palotabozsoki iskolaszék elnöke arról számolt be a tanfelügyelőnek, hogy az egyik édesapa nem szeretné sem internátusban, sem családnál elhelyezni gyermekét, hanem a palotabozsoki iskolába járatná tovább, és kéri, hogy „keülön foglalkozással sajátithassa el a sqü̈kséges magyar ismereteket és erröl év végén külön vizsgát tehessen.” Az indokok között felhozta, hogy a 9 éves gyermek már segítségére van a ház és aprójószág őrzése körül. Az iskolaszéki elnök hozzáfűzte ehhez, hogy „a 100\%-ban német nyelvü iskolaszékei tagok a szülönek ezen kérelmét helyeslik és támogatják. Alulirott iskolaszéki elnök nem lárithatom nevezett szülöt a rendelettel való szembehelyezkedésre, belátom a rendelet nemzetmentó célját, mégis kérem a kérdésnek bölcs megoldását, hogy mindkét kivánságnak eleget tehessünk.” A kérelem nem lett elfogadva, az édesapa végül úgy nyilatkozott, hogy a szomszédos Véméndre fogja járatni gyermekét, külön elhelyezés nélkül. ${ }^{39}$

Az előző esetekhez hasonlóan a püspöknádasdi plébános leírta a tanfelügyelőnek még a tanév kezdete előtt, hogy a magyar anyanyelvú iskolakötelesek szüleit összehívta, nyilatkozzanak arra vonatkozólag, hogy gyermekeiknek tisztán magyar nyelven leendő oktatását magyar községben családi elhelyezés vagy internátusban való elhelyezés útján kívánják-e biztosítani. A szülők szerint mindkét féle elhelyezés sok nehézséggel jár, gyermekeiket nem szívesen adják ki a családból, mert leánygyermekek, még fiatalok is, és „, amit az édesanya ad a gyermeknek, ą̧ sehol nem adják meg.” A szülők itt is megtették azt az indítványt, hogy a hat gyermek után családi elhelyezés esetén járó térítés összegéből alkalmazhatnának egy tanítónőt, ,igy a gyermekek a családban is maradnának és magyar oktatásban is részesülnének.”. A tanfelügyelő erre való válaszában tájékoztatta a plébánost, hogy a gondviselők megnyugtatására magánjellegű körlevelet küldött személyre szólóan az érintetteknek, majd azzal folytatta „ezúton kérem, hogy a nép elött újszerü megoldású nehéz beiskoláási munkában a fenti levél érvei és gondolatai alapján sziviveskedjéke támogatni bivatalomat s az aggályoskodó szülöket megnyngtatni. Hiszem, hogy szives kö̈benjárása meghozza az eredményt és a kért nyilatkozatok mihamarabb beérkeznek bivatalomba. A szülök indítványát - mely szerint az állam által kilátásba belyezett $35 \mathrm{P}$ eltartási költségen ttónö́t fogadnának gyermekeik magyar oktatására - nem vehetem érdemi tárgyalás alá. Ez a megoldásmód a VKM úr 25.360/1941 s\% rendeletének feltételeivel és szándékaival ellentétes lenne, ugyanis bivatkozott rendelet magyar környezetben kivánja biztositani a magyar tankötelesek anyanyelvi oktatását." ${ }^{40}$

\section{3. Összegzés}

A tanfelügyelő által idézett szöveg is mutatja a megvalósítás nehézségeit, ezzel együtt megállapítható, hogy a szórvány magyar tankötelesek iskoláztatása az 1941-1942. tanévben különös szervezőmunkálatot igényelt mind a tanfelügyelőség, mind a szülők, gondviselők részéről. A

\footnotetext{
38 MNL BAML XIV. 70. 1527-57/1941.

${ }^{39}$ MNL BAML XIV. 70. 1527-III-49/1941.

40 MNL BAML XIV. 70. 1527-104/1941.
} 
kiindulási alap az volt, hogy a nemzetiségek nyomására ekkor bevezették a teljes anyanyelvi oktatást, amely a község többségi lakosságához igazodóan lett kialakítva. Ez sok helyen ahhoz vezetett, hogy a magyar tagozat megszűnt, mivel nem volt adott esetben elegendő létszámú - 20 főnél már lehetett kérni a magyar tagozatot - magyar anyanyelvü gyermek, ugyanakkor azok, akik magyar származásúak voltak, nemzetnevelési szempontból nem is járhattak máshova, mint magyar iskolába. Ennek biztosítására kellett a nem magyar környezetben élő magyar gyermekeket családjukból kivenni és internátusban vagy magyar környezetben lakó ismerős illetve rokon családnál elhelyezni. Több szülő kereste fel közvetlenül vagy az iskolaszékeken keresztül azzal a panasszal a tanfelügyelőséget, hogy sem internátusban, sem más családnál nem akarják elhelyezni gyermekeiket. Ennek számos oka lehetett, például megjelent egyrészt az, hogy érzelmi alapon nem akarták kiadni a gyermekeket családból, akár a háborús helyzetre tekintettel, akár egyszerủen féltésből; másrészt anyagi indokok is állhattak a háttérben, mert nem tudtak a gyermeknek ruhát biztosítani, vagy szükség volt a gyermek munkavégzésére a családi gazdaságban.

A szülői felvetésekre a tanfelügyelő sablonválaszlevelet készített, amelyben összegezte a felmerült problémákat, körülményeket, valamint a jogalkotói szándékot is, mindez összefoglalja a tanév szervezési munkálatainak problémáit és eredményeit: „A valóságot és az elóalló új helyzetet okosan felismerō szülök legtöbbje a Pécsett, Mohácson létesitendō tanuló otthonba kérte gondviseltje felvételét. A sұülōk más része a családi elhelyezés módját választotta, / föleg rokon családnál kivánják elhelyezni gyermekeiket/. Örömmel tapasz̨altam, hogy a szülök megértették és eleget tettek országunk sorsa és jobb jövöje érdekében kiadott miniszteri rendeletnek. (...) De azzal már nem érthetek, egyet, hogy azok, akik nem látják kellökép a minisżter ur szándékeát, tiltakozzanak olyasmi ellen, mit nem ismernek. Ezek a szülök tájékozatlanságukban és nyilván nem rosszakaratu tévedésükben bizalmatlanok a jószándékkal szemben, és nem gondolnak arra, hogy ennek a megygyarapodott országnak felelós vežetói vannak, akiknak a sok ez̧er magyar gyermek sorsa iránti féltésen kivül, intézłkedésükért nemzeti és történelmi felelösséggel tartoznak az ország népei elött. Ezért nem érthettem meg egyes szülök szabadkozását, mert a szülöke tiltakozásukekal elébe vágtak, de meg nem értették. ennek az egész országunk életében nagyjelentöségü rendelkęéseknek tulajdonképeni okát és célját. (...) Ez alkalommal nem sorolhatom fel mindazokat az elönyöket, melyeket a magyar állam sulyos anyagi áldozatokkeal járó tanulo-otthonban kap az oda felvételt kérö magyar gyermek, de bizonyos, hogy a gyermek kifogástalan ellátásban részesül, és hivatásos tanitónevelök gondoskodnak testi és lelki fejlódéséröl és állandó orvosi felügyelet alatt lesžnek a gyermekek. (...) nem kell félniök a szülöknek, hogy a kisebb gyermek anyai sžeretet és gondoskodás nélkül marad. (...) Ismétlem az. állambatalom nem akarja a szülöt gyermeket egymástól elidegeniteni vagy elszakitani, a szülók bármikor felkereshetik az otthonban gyermekeiket, meggyőzódhetnek azok ellátásáról, és ha ugy találják, hogy gyermekeiket megfelelöbb helyen tudják elhelyezni, ebben senki sem akadályozza meg öket. Egyben azt is szives tudomásukra

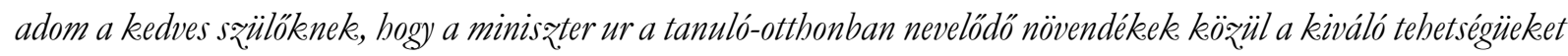
középiskolába államköltségen tovább tanittatja. (...) Végül arra kérem, hogy elhatározását tisztán gyermekének sorsa iránti elórelátása, és hazája iránti kötelességtudata irányitsa." ${ }^{\text {*11 }}$

\footnotetext{
${ }^{41}$ MNL BAML XIV. 70. 1527/1941.
} 


\section{Felhasznált irodalom és források}

1940. évi XX. törvénycikk az iskolai kötelezettségről és a nyolcosztályos népiskoláról.

A m. kir. vallás- és közoktatásügyi miniszter 1941. év 25.370. számú rendelete, a nem magyar anyanyelvű gyermekek népiskolai oktatásáról

A m. kir. vallás- és közoktatásügyi miniszter 1941. évi 25.360. számú rendelete, a magyar anyanyelvű gyermekek iskoláztatásáról

FÜZES Miklós: A nemzetiségi oktatás szervezési problémái a baranyai népiskolákban az 1923/24 - 1943/44 tanévekben. In: SzITA László (szerk.): Baranyai helytörténetírás. Pécs 1979, 384-440.

Magyar Nemzeti Levéltár Baranya Megyei Levéltára (MNL BAML) XIV. 70. Balázs Ferenc VKM nemzetiségi iskolaügyi referens irathagyatéka: 1527-2/1941, 2245/1941, 1527-5/1941, 1527-7/1941, 1527-8/1941, 1527-4/1941, 1527-11-12-9/1941, 1527-13/1941, 1527-14/1941, 1527-18/1941, 1527-19/1941, 1527-21/1941, 152723/1941, 1527-24/1941, 1527-27/1941, 1527-30/1941, 1527-33/1941, 1527-34/1941, 1527-36/1941, $1527-$ 37/1941, 1527-38/1941, 1527-39/1941, 1527-41/1941, 1527-49/1941, 1527-52/1941, 1527-56/1941, 1527 57/1941, 1527-58/1941, 1527-59/1941, 1527-60/1941, 1527-61/1941, 1527-65/1941, 1527-68/1941, 1527 78/1941, 1527-79/1941, 1527-80/1941, 1527-81/1941, 1527-82/1941, 1527-106/1941, 1527-12-13/1941, 1527-III-17/1941, 1527-III-18/1941, 1527-III-25/1941, 1527-III-21/1941, 1527-14-26/1941, 1527-2724/1941, 1527-32/1941, 1527-27-87/1941, 1527-22/1941, 1527-III-41/1941, 1527-III-42-1941, 1527-III43/1941, 1527-III-44/1941, 1527-III-45/1941, 1527-III-46/1941, 1527-III-47/1941, 44-III-21-29-39/1942, 110-1/1942, 80.125/1944, 464/1942, 1527-III-38/1941, 438/1943, 3979/1943, 1527-242/1941, 1527-3233/1941, 1527-104/1941, 1527-III-39/1941, 115/1942, 44-III-20/1942, 1527-III-40/1941, 1527-105/1941, 1527-86/1941, 1527-87/1941, 1527-96/1941, 1527-97/1941, 1527-98/1941, 547/1941, 568/1941, 419/1941, 1527/1941, 1527-26/1941, 351/1941, 1527-69/1941, 1527-III-49/1941.

NIKLAI Patrícia Dominika: A kisebbségi iskolaügy Balázs Ferenc tevékenysége alapján 1938-1944 között. Díké 2020/2. sz. 81-107.

NiKLAI Patrícia Dominika: Die Volksunterrichtspolitik von Bálint Hóman und die Schulgründungen im Komitat Baranya zwischen 1932 und 1942. Beiträge zur Rechtsgeschichte Österreichs 2020/2. sz. 249-259.

NIKLAI Patrícia Dominika: Magyar kultúrpolitika. Közoktatásügyi igazgatás Baranyában (1933-1945). Díké 2019/2. sz. 86-99.

SzITA László: A magyarországi németség iskolaügyének alakulása a Délkelet-Dunántúlon 1938-1944. In: SzITA László (szerk.): Baranyai helytörténetírás. Pécs 1983, 441-556. 